\title{
Dynamics of volatility spillover between stock market and foreign exchange market: evidence from Asian Countries
}

Khalil Jebran ${ }^{* *}$ and Amjad lqbal ${ }^{2}$

* Correspondence: khaliljebranuom@gmail.com

'Department of Management Studies, University of Malakand,

Chakdara, Pakistan

Full list of author information is available at the end of the article

\section{㳕 Springer}

\begin{abstract}
Background: The purpose of this study is to examine volatility spillover effects between stock market and foreign exchange market in selected Asian countries; Pakistan, India, Sri Lanka, China, Hong Kong and Japan. This study considered daily data from $4^{\text {th }}$ January, 1999 to $1^{\text {st }}$ January, 2014.

Methods: This study opted EGARCH (Exponential Generalized Auto Regressive Conditional Heteroskedasticity) model for the purpose of analyzing asymmetric volatility spillover effects between stock and foreign exchange market.

Results: The EGARCH analyses reveal bidirectional asymmetric volatility spillover between stock market and foreign exchange market of Pakistan, China, Hong Kong and Sri Lanka. The results reveal unidirectional transmission of volatility from stock market to foreign exchange market of India. The analysis reveals no evidence of volatility transmission between the two markets in reference to Japan.

Conclusions: The result of this study provide valuable insights to economic policy makers for financial stability perspective and to investors regarding decision making in international portfolio and currency risk strategies.
\end{abstract}

Keywords: Volatility spillover, Asian Countries, EGARCH, Exchange rate, Stock market

\section{Background}

Over the last three decades, there is rapid growth in international equity investments. The increasing trend in equity investment has lead to increase in high demand and supply of foreign currencies. The high demand of currencies and equity flows has created some interdependence between equity returns and exchange rate returns. The increasing interdependency has also increased the volatility transmission betweens stock and foreign exchange market that has increased the international portfolio risk that is faced by investors, which has further lead to decrease the returns of investors portfolios (Kanas 2000). According to (Ebrahim 2000), it is important to know about how shocks are transmitted across financial markets (stock and currency market) and also to explore the magnitude of their effects. This will further enhance the success of policies implemented by policy makers.

The theoretical consensus regarding the linkages between stock prices and exchange rates can be derived from two widely used models named as; flow oriented model (Dornbusch \& Fischer, 1980) and stock oriented model (Branson and Henderson 1985; Frankel 1983). The flow oriented model (Dornbusch and Fischer 1980) posits that 
positive relationship exist between exchange rates and stock prices. This model is based on the idea that exchange rate is determined by a country's current account balance or trade balance. This model assumes that changes in the foreign exchange rate can effect trade balances and international competitiveness. Therefore, affect the real income and inputs. The phenomena can be explained as; the local currency depreciation ${ }^{1}$ will make domestic firms more competitive by having cheaper exports in international trade. The higher exports will enhance the domestic wealth of firms by appreciating the domestic stock prices of domestic firms. In this aspect, causality will run from exchange rate to stock price.

The stock oriented model (Branson and Henderson 1985; Frankel 1983) suggests that the exchange rate is determined by supply and demand of financial assets (equity and bonds). This model is further classified into portfolio balance model and monetary model. The portfolio balance model posits that negative relationship exist between stock prices and exchange rates. This model suggests that causality runs from stock prices to exchange rates. According to this model, investors hold foreign and domestic assets including domestic and foreign currencies. When domestic assets stock prices increases, so investors intends to buy more domestic assets, which compel them to sell their foreign assets in order to have more domestic currency in hand for the purpose of buying more domestic assets. The increase in wealth of investors due to increase in domestic assets prices motivates them to demand for more domestic assets which in turns leads to increase in interest rates. This will lead to currency appreciation. ${ }^{2}$ The monetary approach however postulates weaker or no relationship of exchange rates and stock prices. In this model, exchange rate is considered to be the price of an asset. As prices of assets are based on future expected prices, similarly exchange rates are also determined by future expected exchange rates. So any factor that changes the expected future value of exchange rate will affect today's value of exchange rate. The factors that cause changes in exchange rates may differ from those factors that brought changes in stock prices. Hence, in such conditions there may be no relationship between stock prices and exchange rates. ${ }^{3}$

The information spillover between the two financial markets (foreign exchange market and stock market) has been studied by many researchers for different countries. Most of the studies have focused on the transmission of volatility between foreign exchange market and stock market. The developed countries have been extensively studied by most of researchers (see for example; Antonakakis 2012; Apergis and Rezitis 2001; Beer and Hebein 2011; Ebrahim 2000; Francis et al. 2006; Grobys 2015; Kanas 2000; Yang and Doong 2004). There are also number of studies of integration of foreign exchange market and stock market of developing countries (for example; Choi et al. 2010; Kang and Yoon 2013; Mishra et al. 2007; Morales 2008; O’Donnell and Morales 2009; Qayyum and Kamal 2006; Yang and Chang 2008). There are also some studies for emerging countries for instance (see, for examples; Adjasi et al. 2008; Fedorova and Saleem 2009; Li and Majerowska 2008; Oberholzer and Boetticher 2015; Okpara and Odionye 2012; Walid et al. 2011).

This study intends to investigate the asymmetric volatility spillover dynamics of stock and foreign exchange market using EGARCH model in Asian countries. One of the rationale behind selection of Asian countries sample is that the literature doesn't provide enough evidence in the specific area. This study aimed to consider a sample of 
developed and emerging markets of Asia. The Asian countries included in this study are; China, India, Hong Kong, Japan, Pakistan and Sri Lanka. The sample constitutes developed country of Japan and markets of China, India, Hong Kong Pakistan and Sri Lanka. The sample also represents three countries from South Asia i.e. Sri Lanka, India and Pakistan; and three countries from East Asia i.e. Japan, Hong Kong and China. The contribution of the study will be in the following aspects. First, instead of analyzing a single country, this study investigates volatility spillover between stock market and foreign exchange market in sample of different Asian countries. Second, this study will add some valuable knowledge to existing literature in terms of selected Asian countries sample. In reference to Pakistan; we only found a single study of Qayyum and Kamal (2006) that employed weekly data covering the period from 1998 to 2006. The contribution of this study in reference to Pakistan is as follow. First, we have used daily data instead of weekly because stock and foreign exchange market trading occurs on daily basis and the shock that arises on daily basis is absorbed in weekly data. Second, we have used data set covering the period from 1999 to 2014. In reference to Sri Lanka, up to best of our knowledge, this study is the first to address volatility spillover between stock market and foreign exchange market. In this aspect, this study will be a novel contribution in reference to Sri Lanka. In context of China, Hong Kong, India and Japan, we have found many studies but with mixture of results like (Chkili 2012) and (Beer and Hebein 2011) reported contrasting results in case of Hong Kong. Similarly, (Mishra et al. 2007) and (Beer and Hebein, 2011) found different results for India. (Kanas 2000; Yang and Doong 2004) and (Beer and Hebein 2011; Francis et al. 2006) found contrasting results for Japan. Therefore there is still a gap to explore knowledge about the volatility spillover dynamics in the selected countries. The other contribution of this study is considering daily data covering period of 15 years in order to examine volatility spillover in long run. The reason behind selection of daily data is to capture more information that we can do in weekly and monthly data. Furthermore, the results of this study will be important for economic policy makers, investors and multinational firms. The policy makers will benefit from this study by knowing the behavior of two markets in order to implement policies for financial stability perspective. Investors will use the information to manage their international portfolio risk and currency risk strategies. This study is also important for multinational firms which intend to manage their international currency exposures.

The remainder of the paper is organized as follows. The second section presents the literature. The third section presents the methods. The fourth section shows the results and discussion. The fifth section presents the conclusions and policy implication.

\section{Review of literature}

There are numerous studies that investigated the volatility transmission mechanism between stock and foreign exchange market. The literature can be divided into three aspects; First, those studies that reveals bidirectional volatility spillover between the two markets; Second, those studies which found unidirectional flow of volatility either from stock to foreign exchange market or from foreign exchange market to stock market; Third, those studies which reported no volatility spillover between the two markets. The bidirectional flow of volatility between the two financial markets has been reported 
by following studies, see (Aloui 2007; Andreou et al. 2013; Chkili 2012; Choi et al. 2010; Francis et al. 2006; Mishra et al. 2007; Qayyum and Kamal 2006; Xiong and Han 2015). Francis et al. (2006) examined US with Germany, Japan, UK and Canada. They observed bidirectional volatility spillover between currency and equity market for German and US countries. The transmission of volatility between the two markets has been found asymmetric in nature. In other study, Aloui (2007) examined US equity and currency market along with 5 major European countries. The analyses were carried out on EGARCH model that confirms bidirectional volatility spillover between equity and currency market. They concluded that persistence of the stock prices volatility was more than exchange rate. Qayyum and Kamal (2006) examined the volatility spillover effects of the two financial markets for Pakistan. They concluded statistically significant bidirectional transmission mechanism of stock returns and exchange rate returns. Mishra et al. (2007) empirically investigated the volatility dynamic effects between the two markets with reference to India. Their analyses show clear evidence of bidirectional flow of shocks between the currency and equity market. Recently, similar results have been reported by (Kumar 2013; Panda and Deo 2014) for India. Choi et al. (2010) empirically investigated the New Zealand currency and equity market for volatility transmission mechanism. They concluded bidirectional mechanism of volatility for the two financial markets. Chkili (2012) investigated 8 emerging markets i.e. Argentina, Brazil, Hong Kong, Malaysia, Singapore, Mexico, Indonesia and South Korea by using BEKK-MGARCH model. Their analyses reveal bidirectional shock spillover between two financial markets in most cases. Andreou et al. (2013) analyzed 12 emerging markets including six from Asia and six from Latin America. The analyses reveal bidirectional volatility spillover between equity and currency market. Recently, Xiong and Han (2015) reported bidirectional volatility spillover between the two markets for China.

The unidirectional transmission of volatility between equity and currency market has been reported by following studies (Adjasi et al. 2008; Antonakakis 2012; Beer and Hebein 2011; Chkili and Nguyen 2014; Ebrahim 2000; Fedorova and Saleem 2009; Kanas 2000; Kang and Yoon 2013; O’Donnell and Morales 2009; Okpara and Odionye 2012; Yang and Doong 2004; Yang and Chang 2008). Ebrahim (2000) empirically examined the flow of volatility of exchange rate on the developed equity markets. The empirical evidence show asymmetric unidirectional price spillover for all the selected models. Kanas (2000) made an attempt to explore the developed equity countries i.e. France, Germany, US, Japan, Canada and UK for transmission of volatility between the two markets. He found significant unidirectional volatility effects flowing from equity returns to exchange rate returns for all economies except Germany. In other study, Yang and Doong (2004) extended the literature for G7 countries for currency and equity market spillover effects. Their results show evidence of unidirectional transmission of shocks from equity to exchange rate market for United States, France, Italy and Japan. O'Donnell and Morales (2009) investigated Hungary, Slovakia, Czech republic and Poland. In case of Czech Republic and Slovakia, they reported unidirectional flow of volatility from currency rates to equity prices. Adjasi et al. (2008) empirically investigated Ghanaian stock and currency market and found significant spillover from currency returns to equity returns. Beer and Hebein (2011) made an attempt on studying the G8 countries with South Korea, Hong Kong, India and Philippines. The unidirectional 
shock flow has been observed from currency market to equity market for Japan, India, US, Korea and Canada only. Yang and Chang (2008) carried out a study on Taiwan, South Korea, Japan, Singapore and USA and reported unidirectional asymmetric shock spillover from equity to currency market. Fedorova and Saleem (2009) examined the shock spillover of currency with equity market in European countries. Their empirical evidences showed currency spillover to equity market for all countries except Czech Republic. Okpara and Odionye (2012) empirically found unidirectional transmission of shocks from exchange rate to equity market for Nigeria. Antonakakis (2012) examined cross border currency shock spillover before and after Euro and other currency including Japanese yen, Swiss France and British Pound. They found evidence of cross border shock spillover for all currencies. Kang and Yoon (2013) reported unidirectional flow from exchange rate market to equity market of volatility with reference to Korea. Chkili and Nguyen (2014) recently examined the BRICS countries i.e. Brazil, Russia, India, China and South Africa. They used regime switching model and found volatility spillover from stock prices to exchange rate with no feedback from exchange rate.

In contrast to empirical evidences discussed in above literature, there are also studies that reported no evidence of flow of volatility between stock market and foreign exchange market, see (Apergis and Rezitis 2001; Kearney and Daly 1998; Morales 2008). Apergis and Rezitis (2001) extended the literature for New York and London and found no evidence of volatility transmission between currency and stock market. Morales (2008) empirically studied Six Latin American countries; Venezuela, Argentina, Mexico, Brazil, Colombia and Spain with a European country and found no clear evidence of flow of volatility between the two financial markets. Kearney and Daly (1998) tested the stated relationship for Australia and found no evidence of volatility flow between currency market and stock market.

\section{Methods}

Data

In order to examine volatility spillover between stock market and foreign exchange market, we selected daily data covering period from $4^{\text {th }}$ January, 1999 to $1^{\text {st }}$ January, 2014 yielding a total of 3912 observations. The reason for using daily data is to capture more information than we can do in weekly and monthly data. The data for the selected equity markets of Asian countries is taken from Yahoo finance.com. The stock market data is in daily closing stock prices indices. The data for exchange rates are obtained from oanda.com. The data of all the selected exchange rates for the selected countries is in local currency in terms of US dollar. The data of stock prices and exchange rates consist of 5 trading days i.e. from Monday to Friday. As this study is considering daily data so there were missing observations in many countries data. It is basically due to non-trading at a particular date. The missing observations have been calculated by using interpolation method. This is done in order to capture daily volatility spillover between the two markets. The data of stock prices and exchange rates for each country has been matched with each other on daily basis. The data is considered closing prices of both stock market and foreign exchange market in a specific country to avoid 
timing conflict and to capture volatility transmission. This is done for the purpose of examining volatility spillover aspects on daily basis.

\section{Sample selection}

This study aims to examine Asian countries. The sample includes six Asian countries i.e. China, Hong Kong, Japan, Pakistan, India and Sri Lanka. The sample selection is based on idea to examine the volatility spillover in a sample of developed and emerging markets of Asia. So, the sample constitutes developed country of Japan and emerging markets of China, India, Pakistan, Hong Kong and Sri Lanka. The sample also represents three Asian countries from East Asia; China, Hong Kong and Japan and the rest of the three countries i.e. Pakistan and India and Sri- Lanka from South Asia.

Karachi Stock Exchange (KSE) has been selected as representative stock market for Pakistan. The national currency of Pakistan is Pakistani Rupee (PKR). Colombo Stock Exchange (CSE) is considered for Sri Lanka. The national currency of Sri Lanka is Sri Lankan Rupee (LKR). Bombay Stock Exchange (BSE) is selected for India. The exchange rate of India is Indian Rupee (INR). Shanghai Stock Exchange (SSE) is selected for China. The national currency of China is Chinese Yuan (CNY). Tokyo Stock Exchange (Nikkei) 225 is considered for Japan. The currency used in Japan is Japanese Yen (JPY). Hang Seng Stock Exchange (HSSE) is selected for Hong Kong. The currency used in Hong Kong is Hong Kong Dollar (HKD).

\section{Unit root test}

The time series data is considered non stationary at level. So the preliminary analyses involves checking the stationarity of all the variables using unit root analyses or in other words to know about the order of the integration. The analyses of stationarity is carried out by two commonly used methods i.e. Phillips and Perron (1988) PP and Dickey and Fuller (1979) ADF. Both tests have been carried out to know about order of stationarity of all variables. Both of these tests are well established in literature.

\section{EGARCH model}

The empirical analyses for exploring volatility spillover is aimed to be captured by using Exponential Generalized Autoregressive Conditional Heteroskedasticity (EGARCH) model developed by (Nelson 1991). The simple GARCH model capture symmetric shocks (positive shocks) and is unable to capture asymmetric shock (negative shocks). It is widely argued that negative shocks are likely to create more volatility than positive shocks having the same magnitude. The EGARCH model is able to capture both, symmetric and asymmetric shocks.

Therefore, EGARCH model is selected in order to capture asymmetric volatility spillover between the two markets. The EGARCH model is opted by numerous studies for examining volatility spillover between stock market and foreign exchange market (see for example, (Adjasi et al. 2008; Beer and Hebein 2011; Choi et al. 2010; Kanas 2000; Mishra et al. 2007; Morales 2008; O’Donnell and Morales 2009; Okpara and Odionye 2012; Qayyum and Kamal 2006; Yang and Doong 2004). This study followed the following step wise procedure for measuring volatility spillover. First, we have computed the returns of stock indices and exchange rates for all countries by using formula; $R_{t}=\mathrm{Ln}$ 
$\left(\mathrm{P}_{t} / \mathrm{P}_{\mathrm{t}-1}\right)$; where $\mathrm{R}_{\mathrm{t}}$ is the return, $\mathrm{Ln}$ is natural $\log , \mathrm{P}_{t}$ is price today while $\mathrm{P}_{t-1}$ is previous day price. The aim of this is to examine the conditional variance of stochastic segments of returns. In second step, the ARCH effect has been tested by taking first lag of all variable and than by applying the $\mathrm{ARCH}$ test and checking the probability of chisquare. The significant value of chi-square represents $\mathrm{ARCH}$ effect in the underlying variable. We examined ARCH effect because EGARCH model can be applied on data in which ARCH effect exists means Auto Regressive Conditional Heteroskedasticity. In other words, there must exist, the problems of autocorrelation and heteroskedasticity in variables. In the third step, we have examined cross market volatility spillover between stock and foreign exchange market in two ways. First, we have generated volatility residual series from a specific EGARCH model for each variable separately. Then after, the generated volatility residual series has been used as a proxy for shock emanating to other market. In examining volatility spillover from foreign exchange market to stock market; we have used the volatility residual series of foreign exchange market as shock emanating to stock market and vice versa. We applied EGARCH $(1,1)$ model in order to examine volatility spillover separately for each selected Asian country.

EGARCH model for volatility spillover from foreign exchange market to stock market

$$
\begin{aligned}
& \mathrm{R}_{\mathrm{t}}=\alpha_{0}+\alpha_{1} \mathrm{R}_{\mathrm{t}-1}+\alpha_{2} \mathrm{R}_{\mathrm{t}-1(\mathrm{ER})}+\varepsilon_{\mathrm{t}} \\
& \mathrm{h}_{\mathrm{t}(\mathrm{SP})}=\beta_{0}+\beta_{1} \mathrm{~h}_{\mathrm{t}-1}+\beta_{2}\left|\frac{\varepsilon_{\mathrm{t}}-1}{\sqrt{\mathrm{h}_{\mathrm{t}-1}}}\right|+\varphi \frac{\varepsilon_{\mathrm{t}-1}}{\sqrt{\mathrm{h}_{\mathrm{t}-1}}}+\delta_{(\text {resid }(\mathrm{ER}))}
\end{aligned}
$$

The equation (1) and (2) represent the EGARCH $(1,1)$ model, which is carried out for examining volatility spillover from foreign exchange market to stock market in each country. The equation (1) is the conditional mean, while equation (2) is conditional variance equation. In equation (1), $R_{t}$ is the return of stock price; $\alpha_{0}$ is intercept; $\alpha_{1}$ is coefficient of stock prices, which measure the effects of previous day return on today's return; $\alpha_{2}$ measures the effect of exchange rates changes on stock returns and $\epsilon_{t}$ is error term. In equation (2); $h_{t}$ (SP) represents log of conditional variance of stock prices; $\beta_{0}$ is the constant of volatility; $\beta_{1} h_{t-1}$ represents the consistency and is a function of

volatility; $\beta_{2} \mid \frac{\varepsilon_{t}-1}{\sqrt{h_{t-1}}}$ captures the reaction of volatility to change in news; $\varphi \frac{\varepsilon_{t}-1}{\sqrt{h_{t-1}}}$ measures asymmetric effect of volatility; while $\delta$ is the parameter that examines volatility spillover from foreign exchange market to stock market. In equation (2), (resid (ER) represents generated volatility residual series of foreign exchange market data. The shock spillover from foreign exchange market to stock market has been examined accordingly for each selected Asian country separately.

EGARCH model for volatility spillover from stock market to foreign exchange market

$$
\begin{aligned}
& \mathrm{R}_{\mathrm{t}}=\alpha_{0}+\alpha_{1} \mathrm{R}_{\mathrm{t}-1}+\alpha_{2} \mathrm{R}_{\mathrm{t}-1(\mathrm{SP})}+\varepsilon_{\mathrm{t}} \\
& \left.\mathrm{h}_{\mathrm{t}(\mathrm{ER})}=\lambda_{0}+\lambda_{1} \mathrm{~h}_{\mathrm{t}-1}+\lambda_{2}\left|\frac{\varepsilon_{\mathrm{t}}-1}{\sqrt{\mathrm{h}_{\mathrm{t}-1}}}\right|+\varphi \frac{\varepsilon_{\mathrm{t}}-1}{\sqrt{\mathrm{h}_{\mathrm{t}-1}}}+\psi_{(\text {resid }}(\mathrm{SP})\right)
\end{aligned}
$$

The equation (3) and (4) represents the EGARCH $(1,1)$ model that has been carried out for investigating volatility spillover from stock market to foreign exchange market in each country. The equation (3) is the conditional mean while equation (4) is 
conditional variance equation. In equation (3), $R_{t}$ is the return of exchange rate; $\alpha_{0}$ is intercept; $\alpha_{1}$ represents effects of previous day return on today returns of exchange rates; $\alpha_{2}$ measures the effect of stock prices changes on exchange rate returns and $\epsilon_{\mathrm{t}}$ is error term. In equation (4); $h_{t}$ (ER) represents log of conditional variance of exchange rate; $\lambda_{0}$ is the constant of volatility; $\lambda_{1} h_{t-1}$ represents the consistency and is a function of volatility; $\lambda_{2}\left|\frac{\varepsilon_{t}-1}{\sqrt{h_{t-1}}}\right|$ captures the reaction of volatility to change in news; $\varphi \frac{\varepsilon_{t}-1}{\sqrt{h_{t-1}}}$ measures asymmetric effect of volatility. The parameter $\psi$ is the coefficient which examines the volatility spillover from stock market to foreign exchange market. In equation (4), (resid (SP)) represents generated volatility residual series of stock market data which has been created through EGARCH model of stock prices for purpose of measuring shock spillover from stock to foreign exchange market. The volatility spillover from stock market to foreign exchange market has been examined accordingly for each selected Asian country separately.

\section{Results and discussion}

The preliminary analyses involve checking the behavior of the data. Table 1 reports the summary statistics of stock market returns and exchange rate returns. The returns are estimated by taking first difference of stock prices and exchange rates. The analyses reveal that Pakistan equity market represents mean daily return of $0.08 \%$ that records the highest mean daily return while stock market of Japan represent mean daily return of $0.004 \%$ that report lowest mean return among the selected equity markets. The stock market of China show mean return of $0.01 \%$; Hong Kong equity market $0.02 \%$; stock market of India $0.04 \%$ and stock market of Sri Lanka show mean daily return of $0.08 \%$. The stock market of India is highly volatile (1.56 \%) followed by China (1.54 \%) while stock market of Sri Lanka is least volatile (1.12\%) among selected equity markets. The analyses show evidence that all the equity markets data is negatively skewed. The Figs. 1, 2, 3, 4, 5 and 6 represent the graphical representation of stock returns of all the

Table 1 Summary statistics

\begin{tabular}{llllll}
\hline Countries & Mean (\%) & SD (\%) & Skewness & Kurtosis & Jarque-Bera \\
\hline Stock Returns & & & & & \\
China & 0.01 & 1.54 & -0.0258 & 7.5784 & 3417 \\
Hong Kong & 0.02 & 1.53 & -0.0755 & 10.9303 & 1025 \\
India & 0.04 & 1.56 & -0.1138 & 9.7135 & 7355 \\
Japan & 0.004 & 1.47 & -0.6614 & 8.8684 & 5898 \\
Pakistan & 0.08 & 1.39 & -0.3471 & 6.0991 & 1644 \\
Sri Lanka & 0.05 & 1.12 & -0.3443 & 23.3727 & 6773 \\
Exchange Rate Returns & & & & & \\
China & -0.0077 & 1.04 & -2.3602 & 56.1120 & 4634 \\
Hong Kong & 0.000026 & 1.28 & 2.3450 & 232.305 & 8574 \\
India & 0.0094 & 3.04 & -0.4613 & 10.3073 & 8842 \\
Japan & -0.0019 & 2.89 & -0.0524 & 5.6247 & 1124 \\
Pakistan & 0.018 & 5.87 & -0.0789 & 14.0504 & 1990 \\
Sri Lanka & 0.016 & 6.01 & 0.1262 & 28.4906 & 1059 \\
\hline
\end{tabular}

Mean represents the mean daily return SD represents standard deviation 


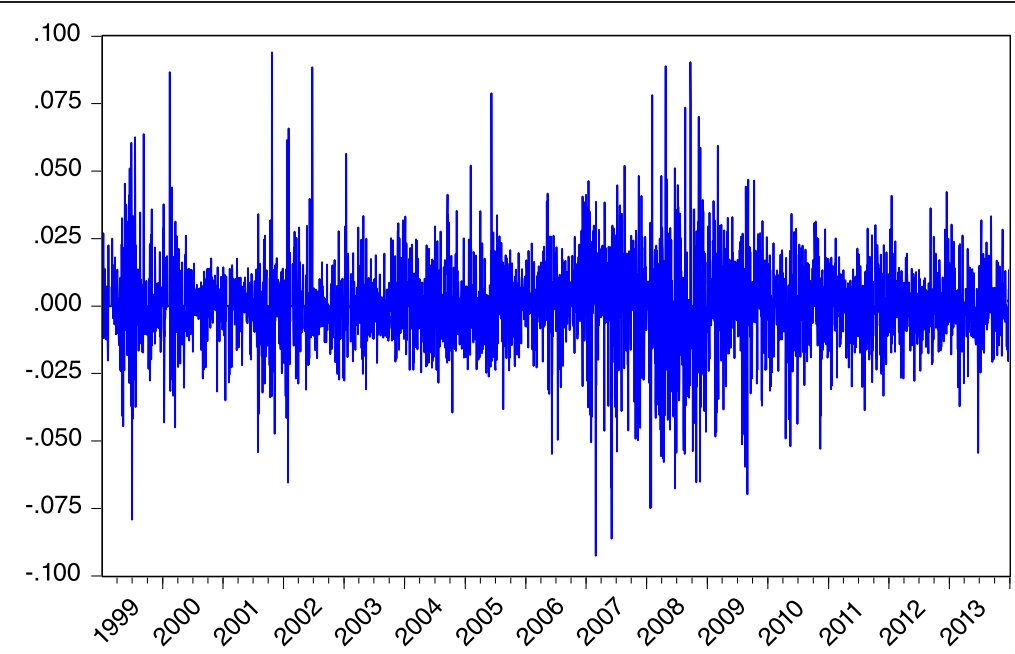

Fig. 1 Stock returns of China

selected countries. The figures of the stock returns elaborates that all the stock market indices represents volatility clusters in the selected period of study. The analyses are based on 3912 observations for both stock prices returns and exchange rate returns.

Similarly descriptive statistics has been carried out to examine the behavior of exchange rates for the selected period of study. Among the selected countries exchange rates, Pakistan exchange rates show highest mean daily return of $0.018 \%$ while Chinese exchange rate shows lowest mean daily return of $-0.0077 \%$. The Japanese currency show mean return of -0.0019 , Hong Kong currency show $0.000026 \%$; Indian exchange rate show 0.0094 \%; whereas Sri- Lankan currency shows mean daily return of $0.016 \%$. The Chinese currency and Japanese currency shows negative mean returns. This might be due to the fact that the local currencies of Japan and China have shown appreciation to US Dollar. The Sri Lanka exchange rate and Hong Kong exchange rate are found positively skewed while Pakistan, India, Japan and Chinese currencies are found negatively skewed. The Chinese exchange rate is least volatile $(1.04 \%)$ while Sri Lanka

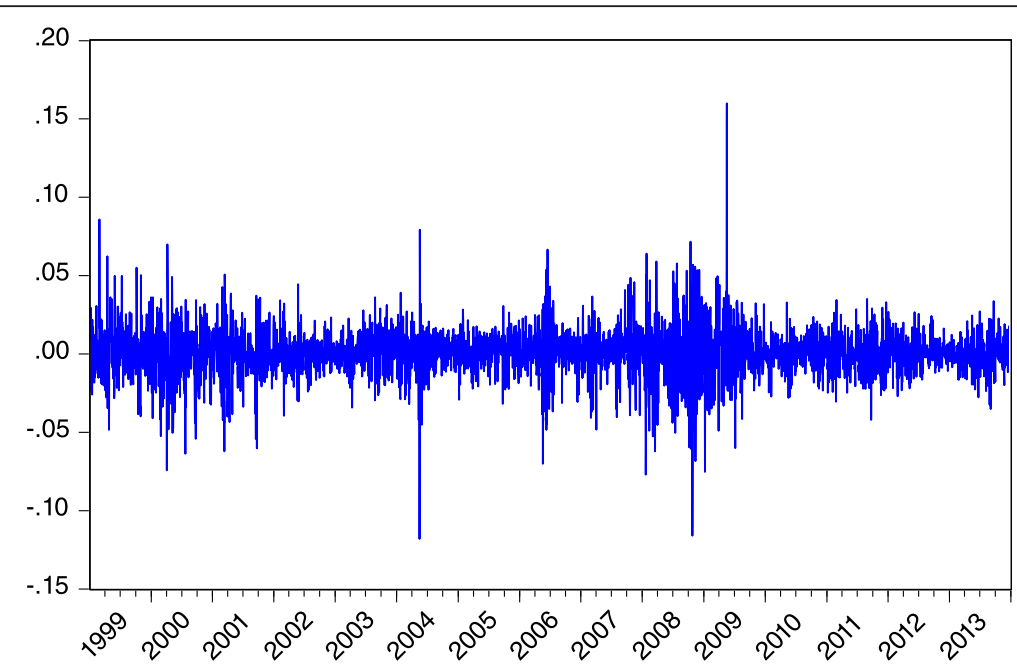

Fig. 2 Stock returns of India 


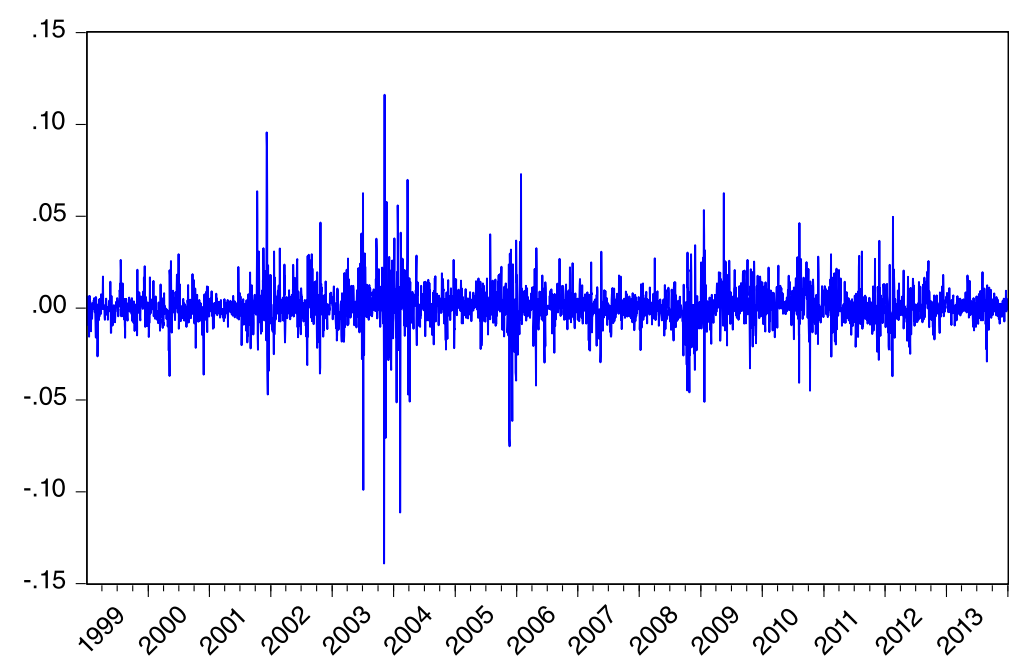

Fig. 3 Stock returns of Sri Lanka

currency is found more volatile (6.01) among selected countries. The Figs. 7, 8, 9, 10, 11 and 12 represents the graphical representation of the exchange rate return of the selected countries. The figures represents that all the selected exchange rate returns show volatility clustering in the selected period.

Table 2 reports the results of unit root tests. The analyses of unit root as mentioned will be performed using two tests named Phillips and Perron (1988) PP test and Augmented Dickey and Fuller (1979) ADF test. The analyses are carried on data by taking natural logarithms of exchange rates and stock prices for all countries. The PP test represents stationarity of all variables at $1^{\text {st }}$ difference. Similarly ADF test show stationarity of all variables at $1^{\text {st }}$ difference.

The transmission mechanism of volatility is aimed to be captured by employing EGARCH model. So the underlying variables (stock prices and exchange rates) have been examined for the purpose of ARCH effect. The ARCH effect represents the presence of autocorrelation and heteroskedasticity issues in data. The EGARCH $(1,1)$

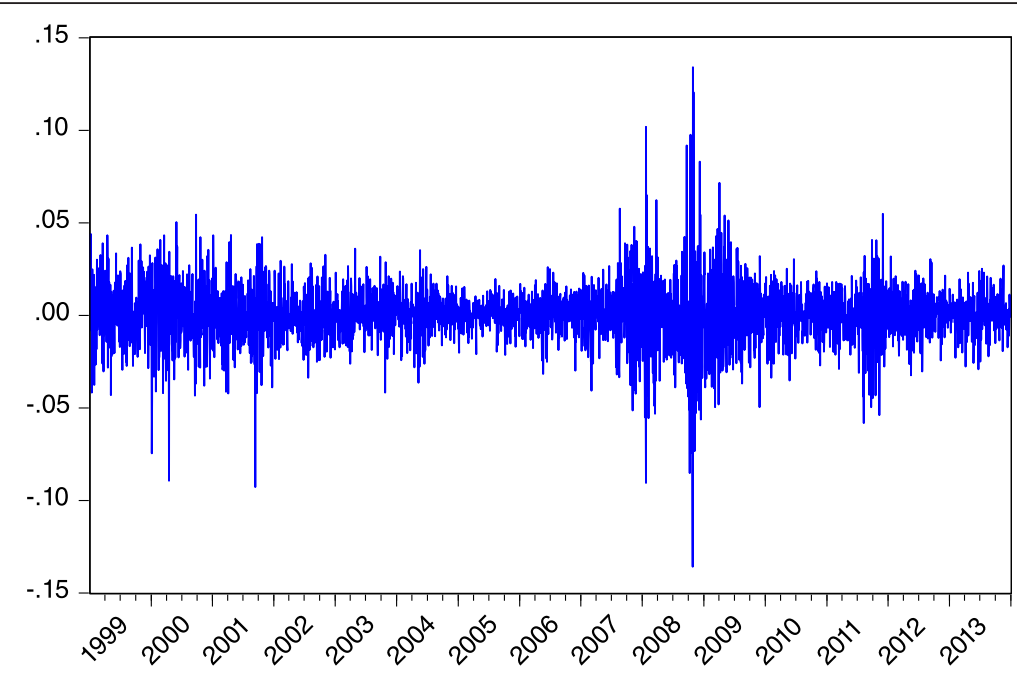

Fig. 4 Stock returns of Hong Kong 


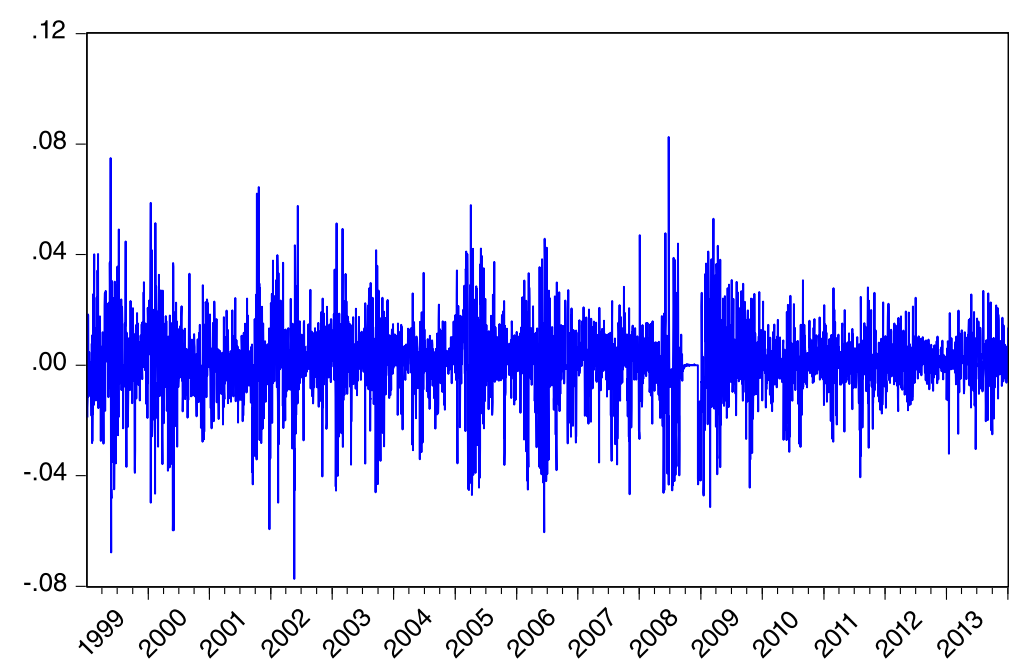

Fig. 5 Stock returns of Pakistan

model can be applied on data having ARCH effect in data. The ARCH effect is tested by taking first difference of the variables and than by applying the $\mathrm{ARCH}$ test. The significant value of chi-square represents $\mathrm{ARCH}$ effect in the underlying variable. Table 3 reports the results of $\mathrm{ARCH}$ test. The result points to the evidence of existence of ARCH effect in all the selected countries stock prices and exchange rates. Hence, we can apply EGARCH $(1,1)$ model.

The final step is to examine volatility spillover between stock and foreign exchange market by employing EGARCH $(1,1)$ model. We have examined each market information spillover separately for each country. First, we have carried out analyses by examining spillover of volatility from foreign exchange market to stock market; after that, we have examined spillover of volatility from stock to foreign exchange market. The suitable lag value for each model is selected on the basis of Akaike information criterion.

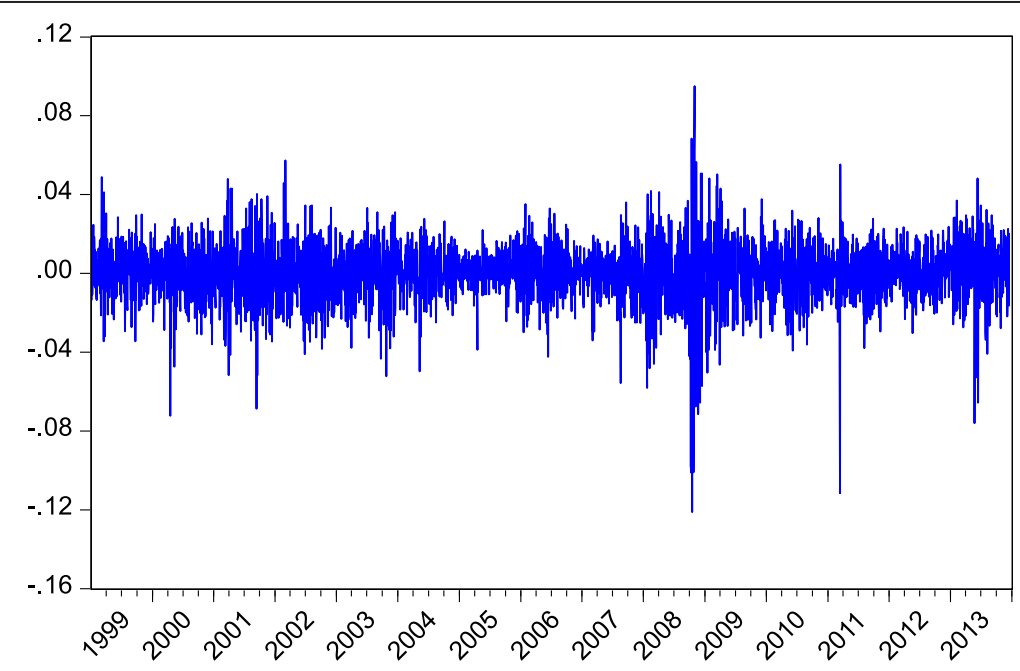

Fig. 6 Stock returns of Japan 


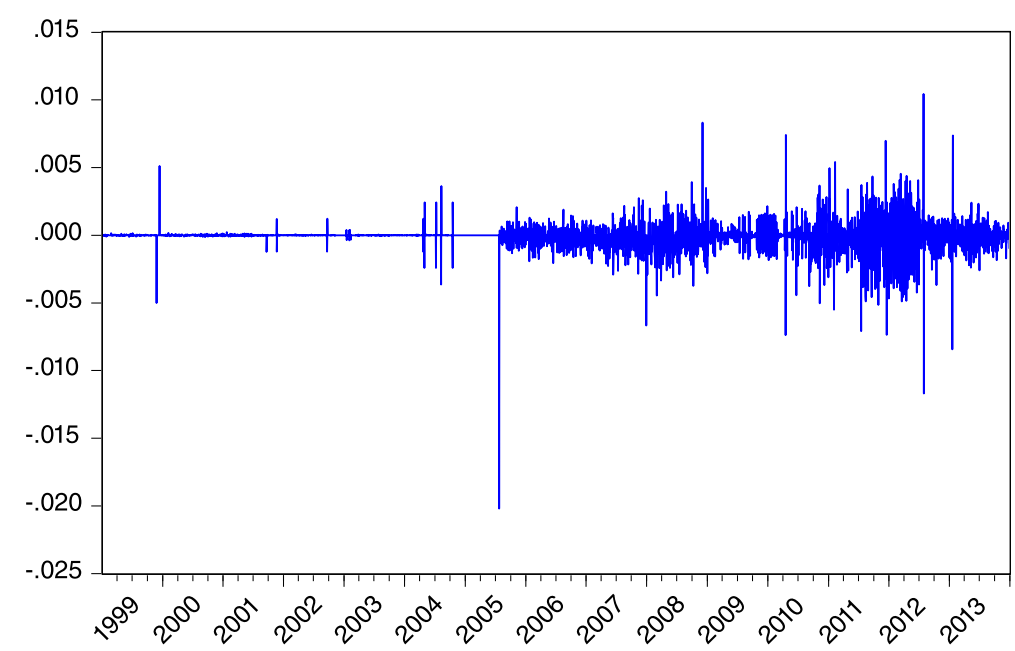

Fig. 7 Exchange rate returns of China

Table 4 reports the estimated results of $\operatorname{EGARCH}(1,1)$ model in which volatility spillover between foreign exchange market and stock market in selected countries are explicitly analyzed. The analyses reveal statistically significant bidirectional volatility spillover between foreign exchange market and stock market of Pakistan. The results of Pakistan tallies with (Qayyum and Kamal 2006). The analyses also show evidence of significant bidirectional spillover of volatility between the two financial markets (stock market and foreign exchange market) for China. In context of Hong Kong, the analyses reveal bidirectional informational spillover between the two financial markets. The results of Hong Kong are consistent with (Chkili 2012). The evidence are however inconsistent with (Beer and Hebein 2011), which reported symmetric volatility spillover (positive shocks have greater effect than negative shocks) between the two markets. The analyses also reveal bidirectional informational spillover between foreign exchange market and stock market of Sri Lanka. In case of India, the analyses doesn't show any evidence of spillover of volatility from exchange rate market to equity market, however

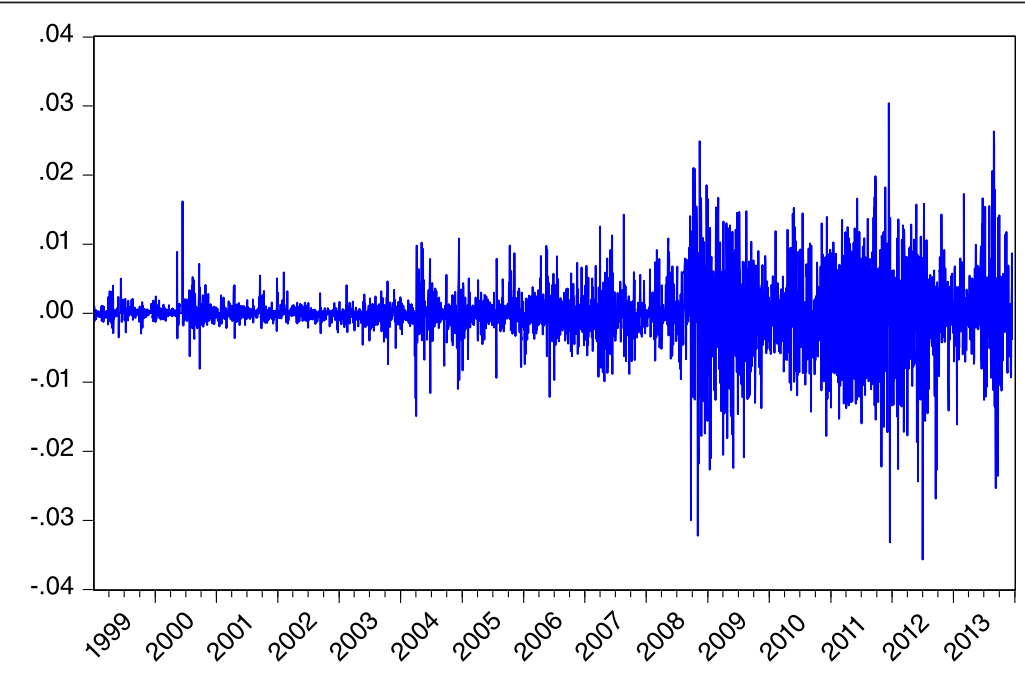

Fig. 8 Exchange rate returns of India 


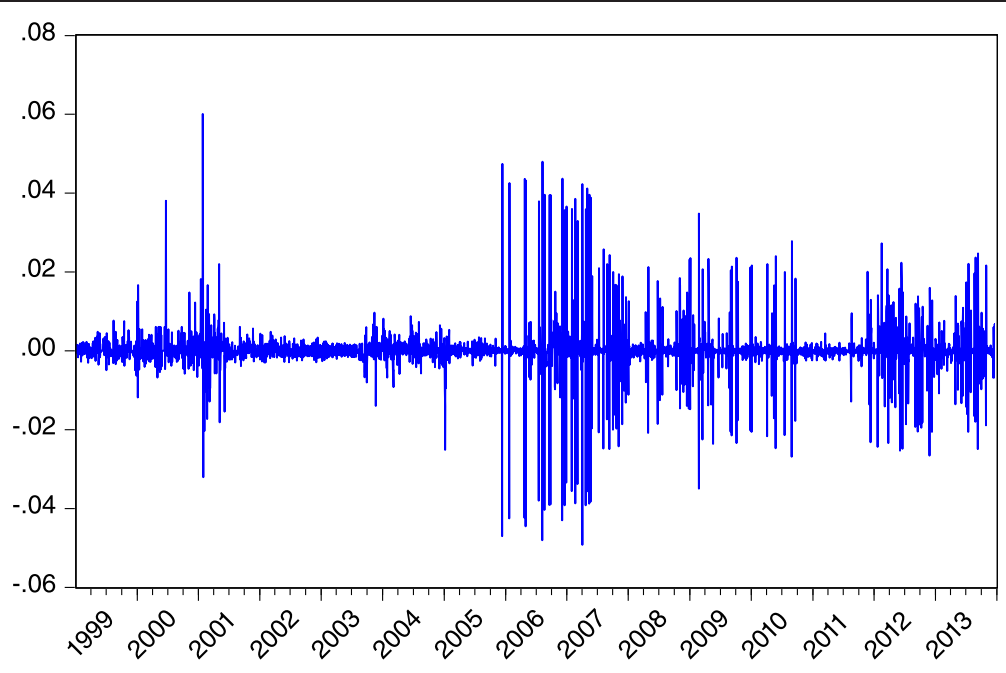

Fig. 9 Exchange rate returns of Sri Lanka

there is significant volatility spillover from stock to foreign exchange market. Contrasting results have been reported by previous studies like (Mishra et al. 2007; Kumar 2013), who reported bidirectional informational spillover for India. Similarly (Beer and Hebein 2011) found unidirectional currency market volatility spillover to stock market for India. The analyses reveal no volatility spillover between the two financial markets in case of Japan. The results for Japan are contrasting with (Kanas 2000; Yang and Doong 2004), who reported spillover from stock returns to exchange rate returns and also (Beer and Hebein 2011; Francis et al. 2006), who found foreign exchange market volatility spillover to stock market. The bidirectional spillover in reference to Pakistan, China, Sri Lanka and Hong Kong was found asymmetric in nature, means negative shocks tends to generate more volatility than positive shocks. The persistence of foreign exchange market volatility was found greater than stock market volatility for all countries.

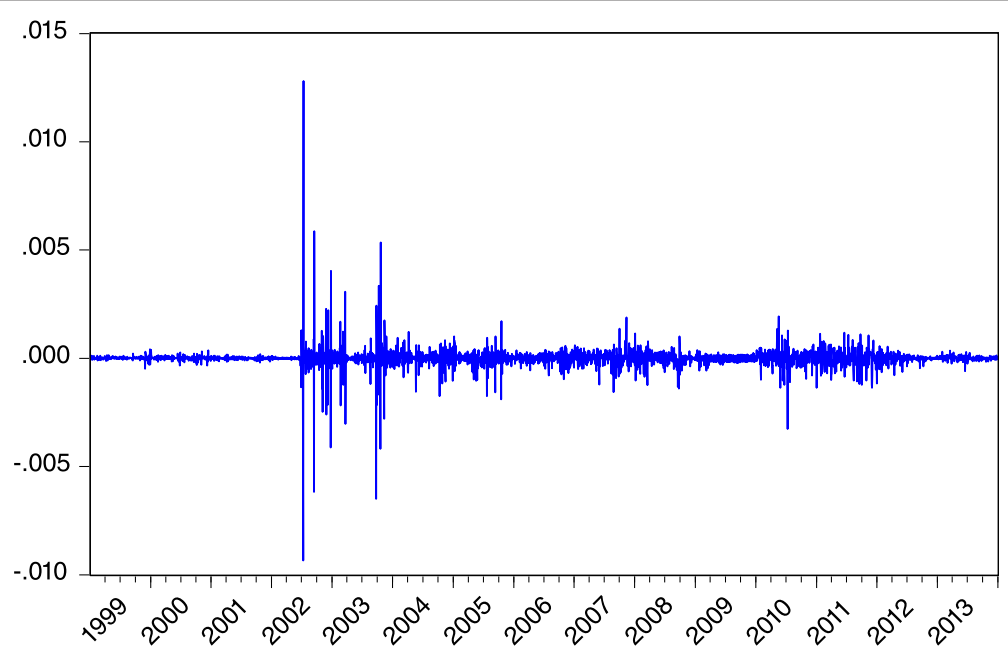

Fig. 10 Exchange rate returns of Hong Kong 


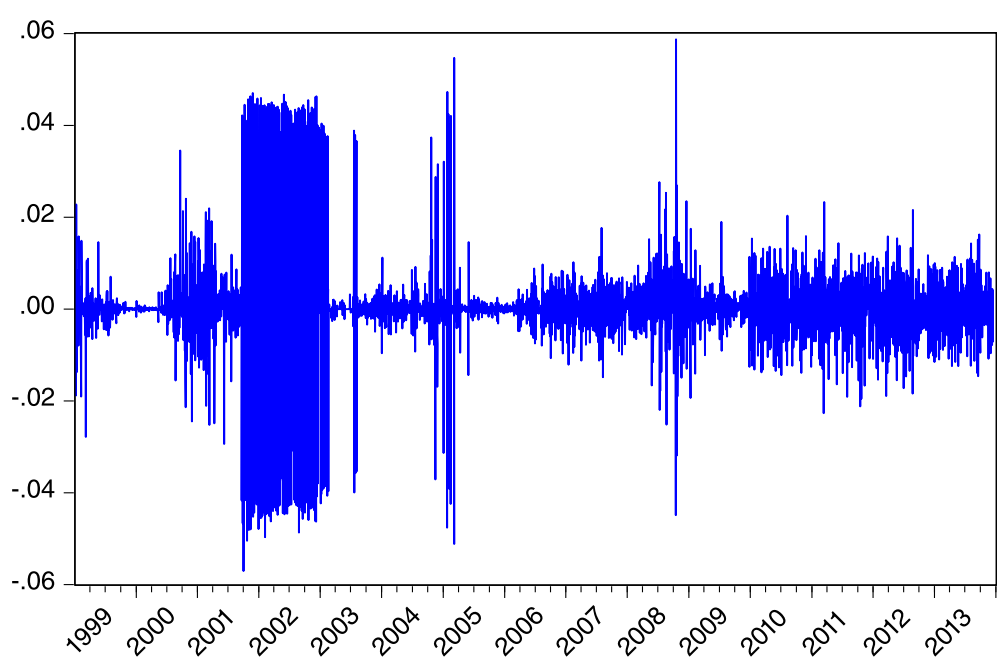

Fig. 11 Exchange rate returns of Pakistan

The mean equation results show that the changes in exchange rate have significant negative impact on stock returns of Pakistan while positive in case of Hong Kong and Sri Lanka; however insignificant for China, India and Japan. The significant negative effect reveal that changes in foreign exchange market reduces stock returns in case of Pakistan. This negative effect has many reasons. One of the reasons is that foreign exchange market decreases the profitability and as well as stock prices of the firms. For economic perspective, there will be negative effect of foreign exchange market fluctuations on international trade, trade balances and country competitiveness. Consequently, it may decrease real income and economic growth. These results in line with number of studies like (Aloui 2007; Walid et al. 2011; Yang and Doong 2004), which reported negative effect of foreign exchange rate volatility on stock returns. These findings support the theoretical prediction of stock oriented model that reveal negative relationship of exchange rate and stock prices. The significant positive effect of foreign exchange

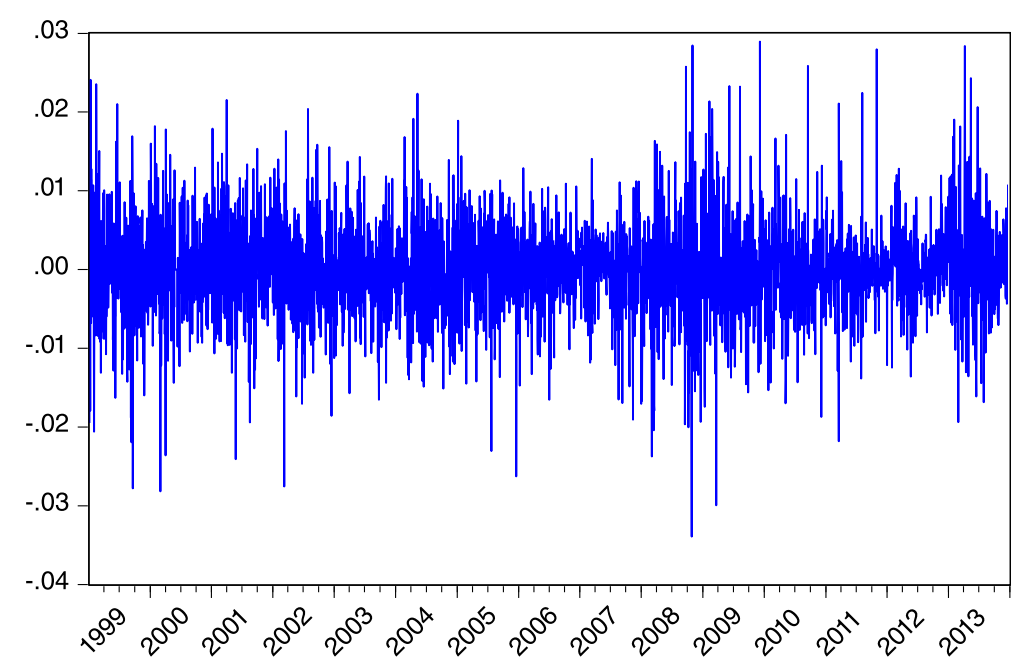

Fig. 12 Exchange rate returns of Japan 
Table 2 Unit root test

\begin{tabular}{lllll}
\hline & PP Test & & ADF Test & \\
\hline Stock Price & & & & \\
& Level & $1^{\text {st }}$ Diff. & Level & $1^{\text {st }}$ Diff. \\
China & -1.81 & $-62.41^{*}$ & -1.78 & $-62.37^{*}$ \\
Hong Kong & -1.83 & $-62.70^{*}$ & -1.83 & $-62.70^{*}$ \\
India & -0.92 & $-57.72^{*}$ & -0.93 & $-57.84^{*}$ \\
Japan & -1.58 & $-63.04^{*}$ & -1.66 & $-62.97^{*}$ \\
Pakistan & -1.11 & $-57.72^{*}$ & -1.15 & $-55.91^{*}$ \\
Sri Lanka & -0.44 & $-50.11^{*}$ & -0.39 & $-40.83^{*}$ \\
Exchange Rates & & & & \\
China & 1.76 & $-9.88^{*}$ & 1.79 & $-73.17^{*}$ \\
Hong Kong & -2.47 & $-46.07^{*}$ & -2.01 & $-84.08^{*}$ \\
India & -0.80 & $-10.57^{*}$ & -0.46 & $-62.57^{*}$ \\
Japan & -1.42 & $-57.51^{*}$ & -1.39 & $-57.51^{*}$ \\
Pakistan & $-12.90^{*}$ & 0.26 & $-125.0^{*}$ \\
Sri Lanka & 0.99 & $-10.16^{*}$ & -1.98 & $-102.1^{*}$ \\
\hline
\end{tabular}

* indicates $p<1 \%$

Critical Values at $1 \%, 5 \%$ and $10 \%$ are $-3.43,-2.86$ and -2.56 respectively $\mathrm{PP}$ is Phillips Perron test

ADF is Augmented Dickey Fuller test

market on stock returns of Hong Kong and Sri Lanka show other scenario as compare to negative effect in case of Pakistan. This represents the phenomena that foreign exchange market increases stock returns of firms. The results support the flow oriented model that postulates positive relationship of exchange rates and stock prices. The insignificant effect of exchange rate effects on stock returns in case of China, India and Japan may reveal the effective hedging strategies against the currency risk in these countries.

Table 3 ARCH Test

\begin{tabular}{llll}
\hline Countries & Constant & AR(1) & ARCH Test \\
\hline Stock prices & & & \\
China & $0.016(0.51)$ & $0.002(0.88)$ & $87.423^{*}(0.00)$ \\
India & $0.044(0.07)$ & $0.077^{*}(0.00)$ & $148.116^{*}(0.00)$ \\
Hong Kong & $0.021(0.37)$ & $-0.002(0.85)$ & $461.452^{*}(0.00)$ \\
Japan & $0.005(0.82)$ & $-0.007(0.65)$ & $255.404^{*}(0.00)$ \\
Pakistan & $0.0755^{*}(0.00)$ & $0.111^{*}(0.00)$ & $384.369^{*}(0.00)$ \\
Sri Lanka & $0.046^{*}(0.00)$ & $0.223^{*}(0.00)$ & $354.024^{*}(0.00)$ \\
Exchange rates & & & \\
China & $-0.009^{*}(0.00)$ & $-0.165^{*}(0.00)$ & $42.029^{*}(0.00)$ \\
India & $0.009(0.20)$ & $4.19 \mathrm{E}-05(0.99)$ & $199.512^{*}(0.00)$ \\
Hong Kong & $3.05 \mathrm{E}-05(0.96)$ & $-0.221^{*}(0.00)$ & $1212.189^{*}(0.00)$ \\
Japan & $-0.001(0.89)$ & $0.084^{*}(0.00)$ & $37.534^{*}(0.00)$ \\
Pakistan & $0.025(0.09)$ & $-0.401^{*}(0.00)$ & $378.305^{*}(0.00)$ \\
Sri Lanka & $0.022^{* *}(0.01)$ & $-0.349^{*}(0.00)$ & $497.900^{*}(0.00)$ \\
\hline
\end{tabular}

Probabilities are shown in parenthesis

ARCH test is the arch effect test

* and ${ }^{* *}$ indicates $p<1 \%$ and $5 \%$ 
Table 4 Volatility spillover between stock and foreign exchange market

Volatility spillover from foreign exchange market to stock market

$\begin{array}{llll} & a_{0} & a_{1} & a_{2} \\ \text { Pakistan } & 0.1308^{*}(0.0118) & 0.0904^{*}(0.0166) & -0.0314^{* *}(0.0316) \\ \text { China } & 0.0274(0.0176) & 0.0036(0.0152) & -0.2383(0.2098) \\ \text { India } & 0.0432^{* *}(0.0176) & 0.09568^{*}(0.0166) & -0.0349(0.0417) \\ \text { Japan } & 0.0036(0.0184) & 0.0040(0.0181) & 0.0566(0.0331) \\ \text { Hong Kong } & 0.0187(0.0178) & 0.0447^{*}(0.0173) & 0.6565^{* *}(0.0352) \\ \text { Sri Lanka } & 0.0395^{*}(0.0101) & 0.2734^{*}(0.0145) & 0.0328^{* *}(0.0156)\end{array}$

$\beta_{0} \quad \beta_{2}$

$-0.2466^{*}(0.0106)$

$-0.0794^{*}(0.0040)$

$-0.1591 *(0.0081)$

$-0.1321 *(0.0096)$

$-0.0878^{*}(0.0074)$

$-0.3666 *(0.0076)$

Volatility spillover from stock market to foreign exchange market

$\begin{array}{lll} & a_{0} & a_{1} \\ \text { Pakistan } & -0.0006^{*}(0.0019) & -0.3272^{*}(0.0162) \\ \text { China } & -0.0033^{*}(0.0005) & -0.1727^{*}(0.0120) \\ \text { India } & -0.0015^{*}(0.0028) & -0.0479^{* *}(0.0148) \\ \text { Japan } & 0.0030(0.0081) & 0.07207^{*}(0.0157) \\ \text { Hong Kong } & 0.0003^{* *}(0.0001) & 0.0581^{*}(0.0125) \\ \text { Sri Lanka } & -0.0086^{* *}(0.0042) & -0.2001^{*}(0.0105)\end{array}$

$a_{2} \quad \lambda_{0}$

$0.0018 *(0.0002$

$-0.0232^{*}(0.0007)$

$0.0864(0.0059)$

$0.00002(0.00009)$

Sri Lanka

$-0.0086^{* *}(0.0042)$

and ** indicates $p<1 \%$ and $5 \%$

For coefficients go to equation 1 to 4

Arch is the arch test on residuals of each model

The figures below the coefficients of arch test are probabilities

$\delta$ represents volatility spillover from foreign exchange market to stock market 
The mean equation also reveal that stock market fluctuations have significant negative effect on exchange rate returns in case of India and Sri Lanka while significant positive in case of China and Pakistan; however insignificant for Hong Kong and Japan. This reveals that increase in stock prices effect exchange rates negatively in case of India and Sri Lanka. The negative effect in which causality runs from stock prices to exchange rate, support the theoretical prediction of portfolio balance model that points to the phenomena that increase in domestic stock prices compel investors to hold more domestics assets, which motivate them to sell their foreign assets in order to have more domestic currency in hand for the purpose of buying domestic assets. The increase in domestic wealth compel investors to demand for more domestic assets leading to increase in interest rates that further leads to currency appreciation. According to Aloui (2007), the effect of stock market on local currency can be explained by the phenomena that stock returns can be used to forecast changes in economic activities denoted by industrial production and profits, real economic growth, and employment rate. The weak or no impact of stock prices on exchange rate in case of Hong Kong and Japan supports the theoretical prediction of monetary approach that postulate no relationship of exchange rate and stock prices.

The variance equation results indicate that the coefficient $\delta$ measuring volatility spillover from foreign exchange market to stock market is positive in case of Pakistan and Sri Lanka, while negative in case of China and Hong Kong. The positive coefficient indicates that foreign exchange market volatility is increasing the volatility of stock market while negative coefficient reveals that foreign exchange market volatility is decreasing volatility of stock market. The positive coefficient results are in line with (Mishra et al. 2007).

The variance equation also indicates that the coefficient $\psi$ measuring volatility spillover from stock to foreign exchange market is negative in case of China, India, Hong Kong and Sri- Lanka, while positive in case of Pakistan. This negative coefficient indicates that stock market volatility is decreasing volatility of foreign exchange market while positive coefficient indicates that stock market volatility is increasing the volatility of foreign exchange market.

In sum, the results show bidirectional volatility spillover between stock and foreign exchange market of China, Hong Kong, Pakistan and Sri Lanka, while unidirectional volatility spillover from stock to foreign exchange market of China, however show no volatility spillover for Japan. The results imply that in case of a develop country Japan, the no volatility spillover between the two market elaborates effective strategies against the stock market and exchange rate fluctuations. Furthermore, the absence of volatility spillover from foreign exchange market to stock market in case of India would represent the effective hedging strategies against currency risk. The bidirectional volatility spillover in case of China, Hong Kong, Pakistan and Sri Lanka would represent the informational inefficiency of these stock markets. The difference in the relationship of stock and foreign exchange market in the selected sample would represent that the volatility spillover between the two markets is less effective in develop country as compared to an emerging economy.

For checking robustness of the results of our study, we have checked the ARCH effect on the residuals of each model to know whether the ARCH effect still exists in the model after estimation of the model. Table 4 reports the results of $\mathrm{ARCH}$ test that 
reveal that there exists no problem of ARCH effect after estimation of model for all selected countries.

\section{Conclusions}

This study investigated the dynamics of volatility spillover between stock market and foreign exchange market in Asian countries i.e. China, India, Japan, Hong Kong, Pakistan and Sri- Lanka covering the period $4^{\text {th }}$ January, 1999 to $1^{\text {st }}$ January, 2014. In this study, EGARCH (Exponential Generalized Auto Regressive Conditional Heteroskedasticity) approach was applied to investigate the asymmetric spillover of volatility between the two financial markets. The empirical evidences show statistically significant bidirectional volatility spillover of stock and foreign exchange market for China, Hong Kong, Pakistan and Sri Lanka. In case of India, the results reveal unidirectional stock market volatility spillover to foreign exchange market. For Japan, the two financial markets (foreign exchange market and stock market) show no evidence of volatility spillover between them. The spillover of volatility in all markets was found asymmetric in nature (negative shocks generate more volatility than positive shocks of same magnitude). The overall persistence of foreign exchange market volatility was found greater than stock market volatility.

The finding of this study has several implications for economic policy makers and investors. For economic policy makers, they may be able to better understand that how the stock market and foreign exchange market volatility effect each other and the economic consequences that may arise by integration of these two markets. According to (Walid et al. 2011), the negative effect of foreign exchange market volatility on stock market may reduce country's competitiveness, international trade and trade balances. In this way, it may adversely effect the economic growth of the country. It is also argued that stock market volatility have non favorable effect on foreign exchange market. This may be explain by the phenomena of portfolio balance model that reveals that increase in domestic stock prices will increase investor's demand for domestic assets, by selling foreign assets in order to have more domestic currency, leading to increase in interest rates that further lead to currency appreciation. In this regard, policies would be formulated and implemented, to manage the volatilities of foreign exchange market and also stock market for financial stability perspective.

For international portfolio managers and hedgers, the volatility transmission between the two financial markets may provide them benefit in predicting the behavior of one market by having the information of other market. Investors can formulate effective hedging strategies against fluctuations of foreign exchange market which can prevent them in future financial crises. They may be able to know about the informational efficiency of the selected countries stock markets. They may be able to manage effective portfolios in the selected countries to enhance their stock returns.

\section{Endnotes}

${ }^{1}$ Depreciation means increase in value of domestic currency.

${ }^{2}$ Appreciation means lowering in value of domestic currency to foreign currency. Hence, there is negative relationship between stock price and exchange rates. 
${ }^{3}$ The overall discussion is based on studies of (Adjasi et al. 2008; Jebran 2014; Kanas 2000; Mlambo et al. 2013; Morales 2008; O’Donnell and Morales 2009; Yang and Doong 2004).

Competing interests

The authors declare that they have no competing interests.

\section{Authors' contributions}

This paper is the part of KJ Master Thesis. Al has contributed in literature review and help in preparing the first and final draft of the manuscript. The authors have read and approved the final manuscript.

\section{Acknowledgement}

Authors are thankful to Dr. Syed Zulfiqar Ali Shah for his valuable suggestions. The authors are thankful to three anonymous reviewers for their helpful comments. The authors have received no financial support.

\section{Author details}

${ }^{1}$ Department of Management Studies, University of Malakand, Chakdara, Pakistan. ${ }^{2}$ Dongbei University of Finance and Economics, Dalian, China

Received: 17 June 2015 Accepted: 6 January 2016

Published online: 01 February 2016

\section{References}

Adjasi C, Harvey SK, Agyapong DA (2008) Effect of Exchange rate volatility on the Ghana stock exchange. African J Acc Econ Finan Bank Res 3(3):28-47

Aloui C (2007) Price and volatility spillovers between exchange rates and stock indexes for the pre-and post-euro period. Quant Finan 7(6):669-685

Andreou E, Matsi M, Savvides A (2013) Stock and foreign exchange market linkages in emerging economies. J Int Financial Market Instit Money 27:248-268

Antonakakis N (2012) Exchange return co-movements and volatility spillovers before and after the introduction of euro. J Int Financial Market Instit Money 22(5):1091-1109

Apergis N, Rezitis A (2001) Asymmetric Cross-market Volatility Spillovers: Evidence from Daily Data on Equity and Foreign Exchange Markets. Manchester Sch 69:81-96

Beer F, Hebein F (2011) An Assessment of the stock market and exchange rate Dynamics in industrialized and emerging markets. Int Busi Econ Research J 7(8):59-70

Branson WH, Henderson D (1985) The specification and influence of asset markets. In: Jones RW, Kenen PB (eds) Handbook of Inter Econ, 2. Elsevier, Amsterdam

Chkili W (2012) The dynamic relationship between exchange rates and stock returns in emerging countries: volatility spillover and portfolio management. Int J Manag Sci Eng Manag 7(4):53-262

Chkili W, Nguyen DK (2014) Exchange rate movements and stock market returns in a regime-switching environment: Evidence for BRICS countries. Res Int Business Financ 31:46-56

Choi DF, Fang V, Fu TY (2010) Volatility spillovers between New Zealand stock market returns and exchange rate changes before and after the 1997 Asian financial crisis. Asian J Finan Acc 1(2):106-117

Dickey DA, Fuller WA (1979) Distribution of the estimators for autoregressive time series with a unit root. J American Stat Assoc 74(366a):427-431

Dornbusch R, Fischer S (1980) Exchange rates and the current account. American Econ Rev 70:960-971

Ebrahim SK (2000) Volatility transmission between foreign exchange and money markets: Bank of Canada working paper 2000-16.

Fedorova E, Saleem K (2009) Volatility spillovers between stock and currency markets: Evidence from emerging Eastern Europe. Czech J Eco Finan 60(6):519-533.

Francis BB, Hasan I, Hunter DM (2006) Dynamic Relations between International Equity and Currency Markets: The Role of Currency Order Flow. J Business 79(1):219-258

Frankel JA (1983) Monetary and portfolio-balance models of exchange rate determination. In: Bhandari J, Putnam B (eds) Economic Interdependence and Flexible Exchange Rates. MIT Press, Cambridge, MA, pp 84-114

Grobys K (2015) Are volatility spillovers between currency and equity market driven by economic states? Evidence from the US economy. Econ Lett 127:72-75

Jebran K (2014) Dynamic Relationship between Stock Price and Exchange Rate: Evidence from Pakistan, China and Srilanka. J Glob Sci Iss 2(2):28-24

Kanas A (2000) Volatility spillovers between stock returns and exchange rate changes: International evidence. J Business Finan Acc 27(3-4):447-467

Kang SH, Yoon SM (2013) Revisited Return and Volatility Spillover Effect in Korea. Korea World Econ 14(1):121-145

Kearney C, Daly K (1998) The causes of stock market volatility in Australia. App Finan Econ 8(6):597-605

Kumar M (2013) Returns and volatility spillover between stock prices and exchange rates: empirical evidence from IBSA countries. Int J Emerg Market 8(2):108-128

Li H, Majerowska E (2008) Testing stock market linkages for Poland and Hungary: A multivariate GARCH approach. Res Int Business Finan 22(3):247-266

Mishra AK, Swain N, Malhotra DK (2007) Volatility spillover between stock and foreign exchange markets: Indian evidence. Int J Business 12(3):343-359

Mlambo C, Maredza A, Sibanda K (2013) Effects of Exchange Rate Volatility on the Stock Market: A Case Study of South Africa. Medit J Soc Sci 4(14):561 
Morales LDN (2008) Volatility Spillovers between Equity and Currency Markets: Eviderice from Major Latin American Countries. Cuad Econ 45(132):185-215

Nelson DB (1991) Conditional heteroskedasticity in asset returns: A new approach. Econometrica: J Econometr Soc 59:347-370 O'Donnell M, Morales L (2009) Volatility Spillovers Between Stock Returns and Foreign Exchange Rates: Evidence from Four Eastern European Countries. Int J Business 12:1-20

Oberholzer N, Boetticher ST (2015) Volatility Spill-over between the JSE/FTSE Indices and the South African Rand. Proc Econ Finan 24:501-510

Okpara GC, Odionye JC (2012) The direction of volatility spillover between stock prices and exchange rate: evidence from Nigeria. Elix Finan 42:6410-6414

Panda P, Deo M (2014) Asymmetric cross-market volatility spillovers: evidence from Indian equity and foreign exchange markets. Deci 41(3):261-270

Phillips PC, Perron P (1988) Testing for a unit root in time series regression. Biometr 75(2):335-346

Qayyum A, Kamal A (2006) Volatility Spillover between the Stock Market and the Foreign Market in Pakistan. Pakistan Inst Develop Econ Working Papers, 2006:7

Walid C, Chaker A, Masood O, Fry J (2011) Stock market volatility and exchange rates in emerging countries: A Markov-state switching approach. Emerg Market Rev 12(3):272-292

Xiong Z. Han L (2015) Volatility spillover effect between financial markets: evidence since the reform of the RMB exchange rate mechanism. Financial Innov 1(1):1-12

Yang YL, Chang CL (2008) A double-threshold GARCH model of stock market and currency shocks on stock returns, Math Comp Simul 79(3):458-474

Yang SY, Doong SC (2004) Price and volatility spillovers between stock prices and exchange rates: empirical evidence from the G-7 countries. Int J Business Econ 3(2):139-153

\section{Submit your manuscript to a SpringerOpen ${ }^{\circ}$ journal and benefit from:}

- Convenient online submission

Rigorous peer review

- Immediate publication on acceptance

- Open access: articles freely available online

High visibility within the field

Retaining the copyright to your article

Submit your next manuscript at $\gg$ springeropen.com 